\title{
THE DOCTRINE THAT LABOR IS A COMMODITY
}

\author{
By Edwin E. Witte, \\ Madison, Wisconsin.
}

The first sentence of section 6 of the Clayton Act states that "the labor of a human being is not a commodity or article of commerce." This declaration is regarded by labor leaders as the magna charta of the wage-earners. It has been heralded as "the dawn of labor's freedom from industrial feudalism and a state bordering upon industrial slavery."

This sentence was something of an afterthought. It was offered as an amendment on the floor of the Senate by Senator Cummins when the Clayton Act was up for passage. It was accepted without so much as a roll-call, and was thought to represent merely a perfection of the phraseology of the section.

No court has ever held that the labor of a human being is a commodity or article of commerce. In discussing his amendment Senator Cummins said:

There are a great many opinions which contain discussions of the subject and which will be found to embrace a course of reasoning which, if carried to its logical end, would put labor precisely where you put a bale of cotton or a bushel of wheat; but these reasons have never found expression in any decision. It has never been so decided. I confess that I have shared the apprehension that some students of the subject have - that the courts may do that in the future. ${ }^{1}$

It was to guard against possible future decisions to the effect that labor is a commodity that Senator Cummins offered his amendment, not to overthrow an established legal doctrine.

On the contrary, there are many decisions which recognize the truth expressed in the Cummins amendment, that the producer is not a product, that labor and the laborer are inseparable. Even in the days of slavery, the labor of slaves was not in law a commodity. ${ }^{2}$ And in construing anti-trust laws the courts have repeatedly held that a combination to increase wages or the reward for personal service is not a conspiracy in restraint of commerce. ${ }^{3}$

${ }^{1}$ Congressional Record, 63d Cong., 2nd Sess., Vol. 51, Pt. 14, pp. 14018-19.

219 Mo. 225.

140 Ia. 182, 107 Minn. 506, 33 Mont. 179. 
Organized labor's insistence upon legislation like the Clayton Act was due principally to the Danbury hatters' case. ${ }^{4}$ In this case, however, there was no suggestion that labor is a commodity. It was charged that the defendants had combined not to monopolize the market for hatters, but to prevent the plaintiffs from freely engaging in interstate commerce in hats. Similarly in all other cases in which the anti-trust laws were invoked in connection with labor disputes, the restraint complained of related to concrete material commodities, not to the labor of human beings.

Organized labor so loudly acclaims the Clayton Act not because of any doctrine that labor is a commodity, but because there is a doctrine that the right to do or continue business is property. Rightly or wrongly, its leaders believe that the Clayton Act, and particularly the Cummins amendment, secures all that the American Federation of Labor sought to gain by the antiinjunction bill which it long championed. This bill provided that federal courts should issue injunctions in connection with labor disputes only for the protection of property rights, and that

no right to continue the relation of employer and employe, or to assume or create such relation with any particular person or persons, or at all, or patronage or good-will in business, or buying or selling commodities of any particular kind or at any particular place, or at all,

should in such cases be regarded as a property right. Such legislation it was thought would make impossible the issuance of injunctions in labor disputes.

This expectation was not unwarranted. It is a debated question whether injunctions may be issued for purposes other than the protection of property rights, and numerous authorities can be cited both pro and con. In cases growing out of labor disputes, however, interference with property rights has always been alleged. Occasionally interference with the physical property of the complainants was claimed, usually only loss of expected profits. If such expectancies had not been regarded as property but few injunctions could have been issued in connection with labor disputes.

Such expectancies arise from the relations of manufacturers with their customers and with their employes. A firm which has established a reputation for fair dealing can reasonably count upon the continued patronage of its customers. If it has paid fair wages

4208 U. S. 274, 235 U. S. 522. 
it likewise can look forward to retaining the services of most of its employes, and to securing other workmen as they are needed. These expectancies have market value; often they sell for more than the physical property. "Property is anything which has exchangeable value" ${ }_{5}$; hence, these expectancies are property.

In cases involving unfair competition, similar expectancies are termed "good-will"; and everybody acknowledges that goodwill should be treated as property. Technically good-will can be interfered with only through duplication or simulation, which never is involved in labor cases. But when a court intervenes to prevent the duplication or simulation of a trade name, a brand, or a product, it protects precisely the same expectancy of continued patronage upon which injunctions in labor cases often are premised. What is called "good-will" in unfair competition cases, is included in "the right to do business or to continue business" so often spoken of in labor cases. But the latter right is somewhat broader. Like good-will, it relates to a fair opportunity in the commodity market; additionally, it guarantees free access to the labor market.

The doctrine that the right to do or to continue business is property does not imply that labor is a commodity. Property rights are never absolute, and this property is peculiarly qualified. The courts recognize that workmen who are not bound by contract may quit their employment at any time, both individually and collectively. Though the employer in consequence suffers loss of profits, he has no legal ground for complaint. But when some outsider maliciously interferes with the relations which he has established with his employes, or prevents him from procuring other workmen as he needs them, he can secure an injunction upon the plea that his property rights are being invaded. Similarly the expectancy of continued patronage is enforcible not against the customers with whom friendly relations have been established, but against malicious intermeddlers. The expectancies which grow out of established relations with customers and employes are property, not because such customers and employes are legally bound to continue these relations, but because they probably will do so, in the absence of unfair interference by outsiders.

As an abstract proposition the doctrine that such expectancies are property cannot be criticized. Such expectancies are a reward

s 16 Wall. $33,127$. 
of honorable and fair dealing. They result from the expenditure of money and effort, and should be regarded as "no less intrinsically property than if the same amount of money had been invested in a stock of merchandise or in a city lot."

The application of this doctrine in concrete cases, however, is subject to many valid criticisms. Undoubtedly it often has been misapplied. Many employers and not a few judges seem to think that all that is necessary to warrant the interposition of equity is to show that there is danger that profits will be reduced. Such a view loses sight of the qualified nature of the property rights in expectancies. The courts are not guarantors of private profits. If expectancies are destroyed as a consequence of the exercise by others of their lawful rights, no wrong has been committed. It follows that employes never should be prevented from quitting work, or from peaceably persuading the workmen who are secured to take their places to join in their strike, though the employer loses all his expected profits. Nor is there anything in the doctrine that the right to do or to continue business is property which forbids workmen from collectively refusing to patronize an unfair employer. This doctrine compels no one to buy who wishes to discontinue his patronage. Nor does it compel every man to be a stranger in action to every other man. Yet this doctrine often has been held to forbid entirely peaceable efforts of workingmen to better their conditions.

The courts, moreover, almost never seem to have inquired whether the expectancies claimed by employers were legitimate. The employers who have come to the courts for injunctions often have been those who pay the lowest wages. Can such employers be said to have any reasonable expectancy of retaining the services of their underpaid employes? Yet the courts often have forbidden all efforts on the part of labor unions to compel such employers to pay the same wages as their competitors. In these cases the courts have lent their aid to the maintenance of profits at the expense of decent conditions of toil. Surely, this is giving property a concept in which it is destructive of human rights.

There is much confusion of thought as to the nature of the right to do or to continue business. Whenever an attempt is made to explain why this right is a property right, it properly is identified

- 78 S. E. 482. 
with the expectancies which arise through fair dealing. But the courts also say that the "right to carry on business" is property, as is the "right to work." Such expressions obscure the essential elements of investment and service. A claim of property in an expectancy should be recognized only when it has its basis in service of the public.

The courts which do not take this view, as Senator Cummins suggests, "employ a course of reasoning which, if carried to its logical end," would make labor a commodity. If the right of employers to carry on their business as they see fit is in fact an absolute property right, as some cases seem to hold, ${ }^{7}$ then the laborer is helpless. What is most surprising, is that the courts which entertain such extreme views try to justify their position upon the ground that it means placing labor upon an equality with property. They develop the thought that the laborer depends for his livelihood upon his labor, and that hence, it is necessary that his right to labor should be regarded as property. But it is significant that such reasoning nearly always occurs in cases in which employers seek the aid of the courts in combating the demands of their employes. The right to work is termed "property" to make the conclusion appear logical, that employers have a property right in keeping down wages. Workingmen derive little or no benefit from the doctrine that the right to do or to continue business is property, nor from its corollary that the right to labor is property. The courts will not protect workingmen from being discharged. Though they lose all the profits which they expected from their employment, they are without redress.

In business law the limitations of property rights in expectancies have been worked out more logically. Good-will, which, as has been noted, relates to much the same expectancies as the right to do or to continue business, is never treated as an abstract right, and is always looked upon as a reward for good service. A monopoly is recognized to have no good-will, precisely because the patronage it enjoys may be due solely to want of choice. Again, the qualified nature of this kind of property is emphasized in business law. When expected profits are lost as a result of fair competition, the courts never intervene. In labor cases, also, it is said that competition is a justification for interference with the ex-

${ }^{7}$ Among others, 147 Ill. 66, 63 Atl. 585, 126 N. Y. Suppl. 949. 
pectancies of others; but the conclusion usually is that the defendants do not compete with the plaintiffs. Workingmen who have undertaken a strike are said to have no further interest in the conditions prevailing in the factories they abandoned; and labor unions are almost always regarded as malicious intermeddlers.

Whether a legal doctrine should be retained, depends quite as much upon how it is applied as upon the conclusiveness of its logic. Though the courts give good reasons why the expectancies, to which the right to do or to continue business relates, should be treated as property, the uses to which this doctrine has been put are indefensible. The practical conclusions drawn from it have been altogether one-sided and grossly unjust. This explains the enthusiasm of organized labor for the Clayton Act. It has come to look upon statements, that business is property, and that the right to labor is property, as equivalent to making labor a commodity; and, hence, it "believes that the declaration that "the labor of a human being is not a commodity or article of commerce" is its magna charta.

It is doubtful whether the courts will hold that this declaration sweeps away the doctrine that the right to do or to continue business is property. This doctrine does not rest upon the proposition that labor is a commodity. While some cases come quite close to such a theory, it is expressed nowhere. It is worthy of note, also, that during the debates in Congress upon the Clayton Act it was given a much narrower meaning than the labor leaders give to it; and President Wilson, while this measure was pending, stated that it would make no radical changes in labor law. Neither the President nor the members of Congress thought that it would prevent the use of injunctions in labor disputes, or that it would make impossible a repetition of the Danbury hatters' case.

It is to be hoped, however, that the Clayton Act will lead the courts to concede workingmen wider freedom to act collectively. This involves more adequate recognition of the qualified nature of the property rights in expectancies. The right to do or to continue business must be treated similarly to good-will in business law. Claims of expectancies must be tested as to their legitimacy; and it must be recognized that the mere loss of profits because of labor disputes is not sufficient to justify the intervention of the courts.

There is little hope for progress, so long as the courts confine 
their attention strictly to precedents and legal theories. Plausible explanations can be given for every doctrine which is met with in trade union law. But both the courts and their critics usually have failed to consider the practical results of the application of these doctrines.

We have not yet heard the last of "the abuse of injunctions" and of "government by injunction." No matter how the Clayton Act may be interpreted finally, injunctions surely will still be issued in connection with labor disputes for many years to come. Similarly, there still will be numerous damage suits growing out of labor disputes. Most cases which involve trade union law come up in the state courts; and but few states have yet enacted legislation similar to the Clayton Act. The "injunction question" is certain further to perplex both the courts and the legislatures. They will find little assistance toward a proper solution of this problem in purely legal discussions. The rights at stake have been threshed out until they are threadbare. In the domain of rights almost everything depends upon the point of departure. If this is the right of workingmen to refuse to work or to purchase, the conclusion is that the losses sustained in consequence of such actions by employers and merchants are incidental. If, on the other hand, the starting-point is the right of employers and of merchants to carry on their business as they see fit, the workingmen's conduct appears as an unwarranted invasion of property rights. The chief value of such discussions is to show how inconclusive is abstract legal reasoning in this field.

The problems dealt with are economic in their nature, and should be considered from this point of view. What is needed most is information about the practical working of legal theories. Article after article has appeared relative to the doctrines which underlie the use of injunctions in labor disputes; but very little about how injunctions are secured, what they prohibit, how they are enforced, and what effect they have upon the outcome of strikes or boycotts. It is questions like these which are vital. This is a time when the law governing controversies between labor and capital is being recast. If a satisfactory law is to evolve, the emphasis must be upon the facts of the present situation, rather than upon abstract reasoning. 